\title{
The role of Nicotiana rustica (Maras powder) in the etiology of bladder carcinoma
}

\section{Mesane kanserinde Nicotiana rustica (Maraş otu) 'nın etyolojideki rolü}

\author{
Taha Numan Yıkılmaz ${ }^{1}$, Serdar Toksoz ${ }^{2}$ \\ ${ }^{1}$ Kahramanmaraş Necip Fazıl Şehir Hastanesi \\ ${ }^{2}$ Hatay Devlet Hastanesi
}

Dergiye Ulaşma Tarihi:16.07.2019 Dergiye Kabul Tarihi:05.08.2019 Doi: 10.5505/aot.2019.98598

\section{ÖZET}

GÍRIŞ ve AMAÇ: Sigara kullanımı mesane kanseri riskini 2-4 kat kadar artırmakla birlikte farklı tütün tipleri ile ilgili bu etki tam olarak kanıtlanamamıştır. Bu çalışmada halk arasında "Maraş otu" olarak bilinen Nicotiana Rustica'nın mesane kanseri üzerindeki araştırıldı. YÖNTEM ve GEREÇLER: Kliniğimizde 2014-2019 yılları arasında mesane tümörü nedeniyle transüretral mesane tümörü (TUR-M) rezeksiyonu gerçekleştirdiğimiz 98 olgunun verileri retrospektif olarak incelenerek 41 olgu çalışma kriterlerine uygun bulundu. Olgular düzenli sigara kullanımı, Maraş otu kullanımı ve hiçbirini kullanmayan olarak 3 ayrı gruba ayrıldı. Elde edilen veriler 1şı̆̆ında gruplar arası karşılaştırma yapıldı. BULGULAR: Çalışmaya uygun bulunan 41 olgunun 29'u (\%71) erkek iken 12 tanesi (\%29) kadın idi. Olguların yaş ortalaması 63 yıl (51-79 yıl) şeklinde hesaplandı. Tüm olgular kullanılan tütüne göre gruplandırıldığında; grup 1 sadece sigara kullanan olgular, grup 2 sadece maraş otu kullanan olgular ve grup 3 ise hiçbir tütün mamülü kullanmayan olgulardan oluşmaktaydı. Olguların \%51'inde sigara kullanım öyküsü mevcut iken; \%15'inde maraş otu kullanımı bulunmaktaydı. Maraş otu kullanan 6 olgunun 5 tanesi günde 5 ten fazla ot kullanmakta iken bunların tümünde T1 tümör izlenmiş 5 ten az kullanımı olan tek olgu ise Ta patolojisine

sahiptir.

TARTIŞMA ve SONUÇ: Maraş otu kullanımı ile mesane kanseri arasında ilişki sigara ile mesane kanseri arasındaki ilişkiye göre zayıf anlamlı kalmıştır. Ancak hiçbir tütün ürünü kullanmayan gruba göre anlamlı derecede yüksek izlendi.

Anahtar Kelimeler: Maraş otu, dumansız tütün, Nicotiana Rustica, mesane tümörü, sigara

\begin{abstract}
INTRODUCTION: It is accepted that smoking increases the risk of bladder cancer by 2-4 times however studies evaluating the relationship between the use of different tobacco types and bladder carcinoma are limited. In this study, the effect of Nicotiana Rustica, known as Maraş powder, on bladder cancer was investigated. METHODS: The data of 98 patients who underwent transurethral bladder tumor (TUR-M) resection due to bladder tumor in our clinic between 2014-2019 were evaluated retrospectively and 41 cases were found to be in accordance with the study criteria. Cases were divided into three groups: regular smoking, Maras powder and none. In the light of the data obtained, a comparison was made between the groups. RESULTS: Of the patients diagnosed with bladder carcinoma, $71 \%$ were male and $29 \%$ were female. The mean age of the patients was 63 years (51-79 years). When all cases were grouped according to the tobacco used; group 1 consisted only of cases using cigarette, group 2 using only smokeless tobacco, and group 3 consisted of cases using no tobacco products; $51 \%$ of these patients smoked and $15 \%$ used Maras powder. It was seen that 5 of the 6 patients who used Maras powder used more than 5 herbs per day and all of these cases had T1 tumors; the only one case with Ta pathology which using less than 5 herbs. DISCUSSION AND CONCLUSION: The relationship between the use of Maras powder and bladder cancer remained poorly significant compared to the relationship between smoking and bladder cancer. However, it was found to be higher than non-tobacco_

Keywords: Maras powder, smokeless tobacco, Nicotiana Rustica, bladder carcinoma, smoking.

\section{GíRiş}

Mesane kanseri sıklı bakımından tüm kanserler arasında 9. sırada ve kansere bağlı

Kanserin insidansı 60-70'li yaşlarda artmaktadır. Bu artış özellikle gelişmekte olan ve az gelişmiş ülkelerde endüstriyel zararlı patojenlere maruziyetin fazlalığına bağlı olarak gözlenmektedir. İleri yaşta gözlenen mortalite
\end{abstract} ölümlerde ise 13. sırada yer almaktadır. 
ve morbiditesi yüksek bir hastalık olması nedeniyle önemli bir halk sağlı̆̆1 sorununa dönüşmüştür (1). Mesane kanserinin etyolojisinde bir çok faktör yer alırken sigara kullanımı en önemli etmen olarak saptanmıştır. Sigara kullanımı mesane kanseri riskini 2-4 kat kadar artırmakla birlikte içme sıklığı, süresi ve miktar1 gibi parametrelerle bu oran değişebilmektedir (2). Örneğin günlük 15 tane sigaradan fazla tüketimin kanser riskini $4.5 \mathrm{~kat}$ artırdığı belirlenmiştir. Sigaranın dumanındaki aromatik aminlerden 4-aminobifebil, nitrozaminler, 2- naftilamin ve akrolein DNA onarımını inhibe ederek etkili olan karsinojenlerdir. Kullanılan tütün tipi incelendiğinde siyah tütünün sarı tütüne göre daha fazla aromatik amin içermesine bağll, kanser gelişim riskinin fazla olduğu bilinmektedir (3). Literatürde sigara içiciliği ve mesane kanseri gelişimi ilişkisini gösteren birçok çalışma varken halk arasında "Maraş otu" olarak bilinen bilimsel adiyla "Nicotiana rustica/Nicotiana tabacum" yani dumansız tütünün etkileri üzerine çalışma bulunmamaktadır. $\mathrm{Bu}$ ot dünya üzerinde pek çok bölgede farklı isimlerle kullanılmaktadır. Güneydoğu Asya ve Hindistan'da "gutka", Bangladeş'te "bidi" ve Türkiye'de de "Maraş otu" adıyla bilinmektedir. Dünya üzerinde 70 'ten fazla ülkede 300 milyon kişiden fazla kullanıcısı bulunması nedeniyle insan vücudu üzerine etkilerini araştırma gerekliliği ortaya çıkmıştır. Alt dudağın arkasına yerleştirme yöntemiyle kulanılmakta olup direkt mukozadan emilerek vücutta etkisini göstermektedir $(4,5)$. Kişilere göre günlük kullanım sayısı değişmekle birlikte ortalama 10 gram kadar ot kağıda yerleştirilerek 5-30 dakika arasında dudak arkasında tutularak emilimi sağlanır. $\mathrm{Bu}$ otu kullanan olguların büyük çoğunluğu otun dudakta yarattığ 1 his kayb1 nedeniyle sigara tüketemediğini bildirmiştir. Bu durum da bize Maraş otu ile sigaranın mesane kanseri üzerine etkisini karşılaştırabilme imkanı sunmaktadır. Bu otun kullanımının kardiyovasküler sistem üzerine etkileri, ağız ve dudak kanserleri ile ilişkisi, immün sistem üzerine etkileri, migren ve uyku bozuklukları ile ilişkisi araştırılmasına rağmen literatürde üroloji alanında özellikle mesane kanserinde bu konuyla ilgili çalışma bulunmamaktadır. Biz de bu çalışmada mesane kanserinde Maraş otunun etkisini sigara kullanımıyla karşılaştırarak değerlendirmeye çalıştık.

\section{MATERYAL VE METOD}

Kliniğimizde 2014-2019 y1lları arasında mesane tümörü nedeniyle transüretral mesane tümörü (TUR-M) rezeksiyonu gerçekleştirdiğimiz 98 olgunun verileri retrospektif olarak incelendi. Olguların ilk tanı anındaki demografik özellikleri, sigara veya benzeri türevlerin kullanım durumu, cerrahi sonrası patoloji sonuçları ve takip verileri kaydedildi. Elli yaşından genç olgular, daha önceden mesane tümörü tanısı almış olgular, başka bir malignite nedeniyle kemoterapi/radyoterapi alan olgular, kronik sondalı ve yeterli datası bulunmayan olgular çalışma dışı bırakıldı. Kırk bir olgu çalışma kriterlerine uygun bulundu. Olguların tamamı primer mesane tümörü olgularından seçildi. İlk başvuru aşamasında rutin laboratuar ve radyolojik tetkiklerin ardindan olgulara sistoskopi ile tanı konularak TUR-M işlemi uygulandı. Operasyon esnasinda tümör ve tümör tabanı olmak üzere en az 2 patolojik preparat gönderildi. Olgular düzenli sigara kullanımı, Maraş otu kullanımı ve hiçbirini kullanmayan olarak gruplandırıldı. Elde edilen veriler 1şı̆̆ında gruplar arası karşılaştırma yapıldı.

\section{SONUÇLAR}

Çalışmaya uygun bulunan 41 olgunun 29'u (\%71) erkek iken 12 tanesi (\%29) kadın idi. Olguların yaş ortalaması 63 yıl $(51-79$ yıl $)$ şeklinde hesaplandı. Tüm olgular kullanılan tütüne göre gruplandırıldığında; grup 1 sadece sigara kullanan olgular, grup 2 sadece maraş otu kullanan olgular ve grup 3 ise hiçbir tütün mamülü kullanmayan olgulardan oluşmaktaydı. Olguları hiç birinde her 2 tütün çeşidini de kullanma öyküsü mevcut değildi. Tüm olguların \%51'inde sigara kullanım öyküsü mevcut iken; \%15'inde maraş otu kullanımı bulunmaktaydı. Olguların demografik özellikleri ve patolojik özellikleri Tablo 1'de özetlenmektedir.

Olguların ilk başvuru esnasında 26'sında (\%63.4) ağrısız pihtılı hematüri şikayeti mevcutken, 9 tanesinde (\%21.9) irritatif mesane semptomları bulunmaktayd 6 tanesinde ise (\%14.6) tanı insidental olarak 
saptand1. Olguların ortalama tümör sayıs1 ve hacmi sirasiyla 1.8 (1-7 tümör adeti) ve $3.5 \mathrm{cc}$ (0.5-9 cc) şeklinde hesaplandi. Cerrahi sonrası patolojik incelemede tüm olgularda papiller ürotelyal karsinom tans1 kondu. Olguların sadece 2 tanesinde (\%5) kas invaziv mesane kanseri (T2) tanis1 konulurken 25 olguda (\%61) Ta, 14 olguda (\%34) ise T1 tanis1 kondu. Olguların 3 tanesinde ise primer tümöre eşlik eden karsinoma in situ (CIS) tanısı mevcut idi. Olguların ortalama takip süreleri 14 ay (5-53 ay) iken 8 olguda (\%19.5) tümör progresyonu 17 olguda (\%41.4) ise nüks gözlendi. Olguların $11(\% 24)$ tanesinde takip eden sürede intravezikal tedaviler uyguland. Olgular tütün kullanımına göre gruplandırıldığında sigara kullanımı olan grup 1 olguların diğerlerine göre istatistiksel olarak anlamlı yüksek görüldüğü izlenmiştir $(\mathrm{p}<0.05)$. Tütün kullanım süreleri incelendiğinde ise süre artıkça evrenin yükseldiği izlenmiş ve anlamlı olarak fark gözlenmiştir. Maraş otu kullanan 6 olgunun 5 tanesi günde 5 ten fazla ot kullanmakta iken bunların tümünde T1 tümör izlenmiş 5 ten az kullanımı olan tek olgu ise Ta patolojisine sahiptir. Yine aynı şekilde sigara kullanım süresi 15 yıldan fazla olan 9 olgunun 5 tanesinde $\mathrm{T} 1$ ve T2 tanis1 mevcut idi. Bu veriler istatistiksel olarak incelendiğinde anlamlı bir yükseklik göze çarpmaktadır (Tablo 2). Bu ististiksel anlama rağmen dumansız tütün kullanımı ile mesane kanseri arasında ilişki sigara ile mesane kanseri arasındaki ilişkiye göre zayıf anlamlı kalmıştır. Bunun nedeninin de bu otu kullanımın farklı şekilleri olması dolayısıyla standardize edilememiş olmasıdır.

Tablo 1: Olguların gruplara göre demografik özellikleri

\begin{tabular}{|l|l|l|l|l|l|}
\hline & $\begin{array}{l}\text { Grup } \\
1 \\
(n: 21) \\
\begin{array}{l}\text { Sigara } \\
\text { kullan } \\
\text { an }\end{array}\end{array}$ & $\begin{array}{l}\text { Grup 2 } \\
(n: 6) \\
\text { Nicotia } \\
\text { na } \\
\text { rustica }\end{array}$ & $\begin{array}{l}\text { Grup 3 } \\
(n: 14) \\
\text { Tütün } \\
\text { kullanma } \\
\text { yan }\end{array}$ & $\begin{array}{l}\text { Topla } \\
\mathrm{m}\end{array}$ & $\begin{array}{l}\mathrm{P} \\
\text { değe } \\
\text { ri }\end{array}$ \\
\hline $\begin{array}{l}\text { Yaş } \\
\text { (y1l } \\
\text { ort.) }\end{array}$ & 60 & 68 & 64 & 63 & 0.03 \\
\hline $\begin{array}{l}\text { Cinsiye } \\
\mathrm{t}\end{array}$ & & & & & 0.00 \\
\hline Erkek & 18 & 5 & 6 & 29 & \\
\hline Kadın & 3 & 1 & 8 & 12 & \\
\hline $\begin{array}{l}\text { Başvur } \\
\text { u }\end{array}$ & & & & & 0.02 \\
\hline
\end{tabular}

Adress for correspondence: Uzm. Dr. Taha Numan YIKILMAZ Kahramanmaraş - Türkiye e-mail: numanyikilmaz@gmail.com

Available at www.actaoncologicaturcica.com

Copyright (CAnkara Onkoloji Hastanesi

\begin{tabular}{|l|l|l|l|l|l|}
\hline $\begin{array}{l}\text { şikayet } \\
\text { i }\end{array}$ & & & & & \\
\hline $\begin{array}{l}\text { Hemat } \\
\text { üri }\end{array}$ & 17 & 8 & 1 & 26 & \\
\hline $\begin{array}{l}\text { İrritatif } \\
\text { şikayet } \\
\text { ler }\end{array}$ & 3 & 1 & 5 & 9 & \\
\hline $\begin{array}{l}\text { İnsiden } \\
\text { tal }\end{array}$ & 1 & 2 & 3 & 6 & \\
\hline $\begin{array}{l}\text { Tümör } \\
\text { adeti } \\
\text { (adet) }\end{array}$ & 1.4 & 1.9 & 2.1 & 1.8 & 0.2 \\
\hline $\begin{array}{l}\text { Tümör } \\
\text { boyutu } \\
\text { (cc) }\end{array}$ & 2.8 & 3.8 & 4.2 & 3.5 & 0.1 \\
\hline
\end{tabular}

Tablo 2: Olgularin gruplara göre evrelendirilmesi

\begin{tabular}{|l|ll|l|l|}
\hline & $\begin{array}{l}\text { Grup } \\
(n: 21)\end{array}$ & $\begin{array}{l}\text { Grup 2 } \\
(n: 6)\end{array}$ & Grup 3 (n:14) \\
\hline Ta $(n: 25)$ & 14 & 1 & 10 \\
\hline T1 $(n: 14)$ & 6 & 5 & 3 \\
\hline T2 $(n: 2)$ & 1 & - & 1 \\
\hline T3 $(n:-)$ & - & - & - \\
\hline
\end{tabular}

Grup 1: Sigara kullanan olgular, Grup 2: Nicotiana rustica kullanan olgular, Grup 3: Tütün kullanmayan olgular

\section{TARTIŞMA}

Dünya Sağlık Örgütünün 2015 verilerine göre dünyada en sik ölüme neden olan hastalık olarak kanserler ilk sirada yer almaktadır. Erkeklerde en sik akciğer kanseri izlenirken kadınlarda meme kanseri ilk sırada gözlenmektedir. Ülkemizde mesane kanseri erkeklerde 4. en sik izlenen kanser olarak kayıtlara geçmiştir (6). Etyopatogenezinde genetik geçişten çevresel faktörlere kadar pek çok faktör yer alırken sigara içiciliği olguların yarısından fazla görülen, kanser riskini 2-4 kat kadar artırabilen bilinen en önemli risk faktörüdür (7). Bu çalışmada Maraş Otu adı ile bilinen dumansız tütünün mesane kanseri üzerindeki etkileri araştırıldı.

Mesane kanseri genel olarak ürotelyumun hasarı sonucu onkojenlerin derin dokulara invazyonu ve tümör süpresör genlerdeki kayba bağlı oluşmaktadır (8). Bu hasarın oluşumunda sigaranın içindeki naftilaminler görev almaktadır ve buna bağlı tütün ürününün tüketim miktarı, süresi ve çeşidi hastalığın gelişiminde önemli bir yer tutmaktadır. Sigaranın mesane kanserindeki etkisini inceleyen çalışmalar literatürde fazlaca yer alırken biz bu çalışmada dumansız tütünün etkisini; sadece sigara kullanan ve hiçbir tütün 
ürünü kullanmayan gruplarla karşılaştırarak inceledik.

Dumansız tütün özellikle Güneydoğu Asya, Güney Amerika ve Türkiye'de de Güneydoğu Anadolu bölgesinde sık kullanılmaktadır. Ucuz, kolay ulaşılabilir ve kapalı yerlerde de tüketilebilmesinden dolayı özellikle genç ve düşük sosyo-ekonomik düzeydeki kişiler tarafından tüketilmektedir. Tütün içermemesinde dolayı sigaraya oranla daha az zararlı olarak kabul edilse de "tütün spesifik nitrozaminler" (TSNA) adı verilen karsinojenleri barındırmaktadır. $\mathrm{Bu}$ karsinojenler gelişim, fermentasyon ve tütsüleme aşamasında oluşmaktadır. Bunları uzun süreli kullanımına bağlı oral kanserler, kardiovasküler hastalıklar ve dişeti hastalıkları s1k gözlenmektedir (9). Literatürde mesane kanseri ile bu tütünün direk ilişkisi gösterilememişse de zararsız olduğu da kanıtlanamamıştır. Bizim çalışmamızda da dumansız tütün ile normal sigaranın mesane kanserine üzerine etkisi araştırılmış, sigaranın hastalığın etyolojisinde belirgin etkisi izlenirken dumansız tütünün etkisinin kontrol grubundan yani hiç tütün almamış bireylerden daha fazla olduğu izlenmiştir. Literatürde dumansız tütünün mesane kanseri üzerine etkisini araştıran pek çalışma bulunmamasına rağmen 2015 yılında Pakistan'da yapılan bir çalışmada dumansız tütün kullanan olgularda mesane kanseri gelişiminin normal popülasyondan fazla görüldüğü ancak sigara kullanan popülasyona göre daha az izlendiği belirtilmiştir. Bu otun kullanım süresi ile tümör evresi arasında zayıf anlamlı bir istatistik saptanmış olup günde 5'ten fazla ot kullanımının mesane tümörü görülmesinde risk oluşturduğu ve sürenin artması ile evrenin yükseldiği görüşü bildirilmiştir(9). Çalışmanın sonuçları bizim çalışmamızla benzerlik göstermektedir. Ancak bizim çalışmamızda ve Türk toplumunda bu otun kullanımı \%15 seviyelerinde iken bu çalışmada oran $\% 47$ düzeyindedir. Bunun nedeni olarak kapalı toplumlarda kadınların kültürel baskı nedeniyle sigara kullanımı yerine dumansız tütün tüketiminin fazla olduğu belirtilmiş ve çalışmaya alınan mesane tümörlü kadın olguların \% 47'sinde dumansız tütün kullanımı rapor edilmiştir. Buna benzer literatürde dumansız tütünün mesane kanserinde etkisini gösteren çalışmalar mevcut iken $(10,11)$ etkisiz olduğunu belirten çalışmalarda bulunmaktadır
(12). Çalışmamızdaki olguların demografik ve kliniko-patolojik özellikleri literatür ile uyumlu şekilde bulunmuştur. $\mathrm{Bu}$ otun kullanım süresi ve miktarının tümör evresini artırdığını gösteren çalışmalara benzer olarak bizim olgularımızda da aynı etki gözlenmiş ancak zayıf anlamlı ilişki izlenmiştir.

Çalışmamızda yeterli hasta sayısının bulunmamas1 nedeniyle yeterli istatistiki çıkarımlar yapılamaması en büyük limitasyon olarak göze çarpmakta iken; grupların randomizasyonu ve tütün kullanımları ile ilgili gruplandırmanın standardize edilmiş olması çalışmanın avantajlarındandır.

Sonuç

Çalışmamızda mesane kanseri gelişiminde Maraş otunun, sigara kadar çok olmasa da etyolojide yer alabileceği gösterilmiştir. Bu otun kullanım süresi ve adeti arttıkça tümör evresinde de artış izlenmiştir. Her geçen gün kullanımı artan bu tütün mamulünün kanser de rol oynayabileceği unutulmamalı ve insanlara bunun zararları aktarılabilmelidir.

\section{REFERANSLAR}

1. Eser S, Zorlu F, Divtik RT, Cal C, Ozkan M, Kirkali Z. Incidence and epidemiological features of cancers of the genitourinary tract in Izmir between 1993-2002. Asian Pac J Cancer Prev. 2009 Jul-Sep;10(3):491-6.

2. Zeegers MP, Tan FE, Dorant E, van Den Brandt PA. The impact of characteristics of cigarette smoking on urinary tract cancer risk: a metaanalysis of epidemiologic studies. Cancer. 2000 Aug 1;89(3):630-9.

3. Lee HW, Wang HT, Weng MW, Hu Y, Chen WS, Chou D, Liu Y, Donin N, Huang WC, Lepor H, Wu XR, Wang H, Beland FA, Tang MS. Acrolein- and 4-Aminobiphenyl-DNA adducts in human bladder mucosa and tumor tissue and their mutagenicity in human urothelial cells. Oncotarget. 2014 Jun 15;5(11):3526-40.

4. İnanç Y, Orhan FO, İnanç Y. The effects of Maras powder use on patients with migraine. Neuropsychiatr Dis Treat. 2018 May 7;14:11431148. doi: 10.2147/NDT.S164818. eCollection 2018.

5. Glover ED, Glover PN. The smokeless tobacco problem: risk groups in North America. Pounds (millions) 1992:3-10.

6. İrer B, Dağ F, Aslan G. Sigara Kullanım Süresinin Mesane Kanserinin Tanı Anındaki Klinik ve Patolojik Özellikleriyle Olan İlişkisinin Değerlendirilmesi. Bulletin of Urooncology 2017;16:108-11 DOI: 10.4274/uob.870 
7. Burger M, Catto JW, Dalbagni G, et al. Epidemiology and risk factors of urothelial bladder cancer. Eur Urol 2013;63:234-241

8. Olumi AF, Skinner EC, Tsai YC, Jones PA. Molecular analysis of human bladder cancer. Semin Urol. 1990;8:270-277.

9. Rafique M. Clinico-pathological features of bladder carcinoma in women in Pakistan and smokeless tobacco as a possible risk factor. World J Surg Oncol. 2005 Aug 5;3:53.

13. 545. doi: 10.1093/jnci/93.7.538.
10. Slattery ML, Schumacher MC, West DW, Robinson LM. Smoking and bladder cancer. The modifying effect of cigarettes on other factors. Cancer. 1998;61:402-408.

11. Kabat GC, Dieck GS, Wynder EL. Bladder cancer in non smokers. Cancer. 1986;57:362-367

12. Castelao JE, Yuan Jian-Min, Skipper PL, Tannenbaum SR, Gago-Dominguez M, Crowder JS, Ross RK, Yu MC. Gender and smoking related bladder cancer risk. J Nat Can Inst. 2001;93:538- 